\title{
POLITICS ON AN 'UNPROFITABLE' ISLAND: RESOURCES AND GATEKEEPERS ON BONAIRE, N.A.
}

The Caribbean is normally discussed in terms of the larger wellwatered islands, suitable for large scale agricultural enterprises; 'Plantation America' is one of the epithets coined for the region. The islands that fall outside this frame of reference usually get far less attention. Recently however, a number of island communities that clearly belong to this last category, such as Aruba and Curaçao have been subject of much scholarly interest (Aruba: GrEEN 1974, KALM 1975; Curaçao: ABRAHAM-v.d. MARK 1969, MARKS 1976, RÖMER 1977, VERTON 1977). We have no account yet of neighbouring Bonaire, the third island, that together with Aruba and Curaçao forms the southern half of the Netherlands Antilles. The attempt to describe and analyse the political field of the island first mentioned, forms the object of this paper. ${ }^{1}$

Bonaire presents us with a rather intriguing case. The island resembles Aruba and Curaçao in a number of ways. To mention just one important characteristic, the dry climate renders it unfit for the cultivation of tropical foodcrops. It therefore lacks 'the continuous interplay of plantations and small-scale yeoman agriculture, with accompanying social-structural effects', listed by MINTZ (1971:20) as one of the major features of Caribbean regional commonality. Thus - just as on the two nearby islands the ownership of land, the usual parameter of social differentiation and inequality, appears to offer little guidance if we look for the crucial relations that structure its political field. But contrary to Aruba and Curaçao, Bonaire also lacks other local resources of any significance. As will be shown the island depends for an over- 
whelming part of its income on external resources; the influence of this particular economic situation on its political life will engage our attention in subsequent pages. ${ }^{2}$

\section{History}

Bonaire, with an area of $284 \mathrm{~km}^{2}$ and about 9000 inhabitants (in 1976), belongs to the group of islands that form the Netherlands Antilles, since 1954 an autonomous part of the Kingdom of the Netherlands. Together with Aruba en Curaçao, Bonaire constitutes the group of so-called 'Benedenwindse eilanden', which are situated close to the Venezuelan mainland. The three 'Bovenwindse eilanden', Saba, St. Eustatius and St. Maarten, form part of the rim of small islands that enclose the Caribbean basin in the North East. ${ }^{3}$ Only about half of the island of St. Martin belongs to the Netherlands Antilles (= Sint Maarten), the other half is French (= Saint-Martin).

The Spaniards classified Bonaire, together with Aruba and Curaçao as 'islas inútiles', that is useless, unprofitable islands, because precious metals were not to be found here. But Bonaire was not only unprofitable in this respect; the scarcity and the unreliability of the rainfall made cultivation a rather hazardous enterprise. For that reason, during most of its colonial history, Bonaire has been exploited as a sort of ranch, initially by the Dutch West-Indian Company and later by the Dutch Government. It supplied Curaçao - a commercial center in the Caribbean - with meat, mainly goat meat. Other Bonairean products were charcoal, lime, dividivi pods (used for the preparation of tannin) and salt. At the end of the 19th century aloë was added to the list (aloine is used in cosmetic and medical products).

In Bonaire's population three elements were discernable: Amerindians, Africans and Europeans. Amerindians were the earliest inhabitants of the island. It is, however, unlikely that their descendants contributed to Bonaire's population, as most of them are said to have been carried off to Hispaniola in the early days of Spanish rule. Later other Amerindians seem to have settled on Bonaire, probably originating from the mainland. The Africans were brought to Bonaire as slaves; they were put to work in the salt- 
pans, while the government officials, soldiers, seamen and artisans were of European origin. In the course of time miscegenation took place to a considerable extent.

All enterprise on the island was in the hands of the government; private persons were not allowed to own land on Bonaire or to carry on trade. However, after the abolition of slavery in 1863 , this situation altered. The government presumed that under the new circumstances a paying exploitation of Bonaire would be unlikely and decided to sell the major part of the island. In 1868 a public auction was held and pieces of land from 1,500 to 10,000 acres came into private possession. Exempted from the auction were the areas near the settlements that were used for subsistence farming; the occupants were afforded the opportunity to buy their plot or to take it on lease from the government. Thus individual landownership and leasehold tenure became the prevailing economic arrangements, with a few big landowners and several hundreds of small holders and tenants. In the course of time, the big landowners, Curaçaoan and Bonairean whites, managed to establish themselves as commercial middlemen. They set up business firms, that did not only sell and export the products of their own 'plantations' and those bought of third parties, i.e. commoners, but also came to control most of the import of the island. Moreover, their schooners had an important share in the transport to and from Bonaire. From an economic point of view commerce proper was the most important source of income, as the produce of the land fluctuated greatly; the 'plantations' were mainly a prestige object that confirmed the position of the shon, as the 'prominent' are called in Papyamentu. Besides, the land has some function for commerce; the labourers on the 'plantation' were bound to the owner by a truck-system, so that at least part of the turnover was ensured. For the common man the work on the plantations or in the salt-pans stood for a very necessary supplement to his income. Owing to climatic conditions the small piece of land he owned or rented did not produce much. It must be stated, however, that in a dry year there was not much work on the plantations either; for that reason many Bonaireans migrated seasonally or (semi) permanently to other islands, to the U.S., or to countries in South America.

The establishment of the oil refineries in Curaçao (Shell, 1918) 
and in Aruba (Esso, 1927) brought this period, that did not bring wealth either to the shon, or to the common man, to a close. On Bonaire a voluminous migration started, directed towards the neighbouring islands. In the years 1925 to 1949 the number of inhabitants decreased from 7,521 to 5,011. In the course of this process Bonaire also lost most of its white shon; nearly all of them moved to Curaçao or Aruba. Their plantations and trading firms came into the hands of people who had acquired some money through skill and industry. Some of them had worked as captains on the sailing-vessels of the former landowners. The new shon continued the seignorial way of life in the old fashion. The importance of agriculture and other local resources, however, diminished rapidly, because of the new and better possibilities for earning an income. Bonaire got what was called a 'money-order' economy.

After the second world war, the changes in the island's economy that were already noticeable before that period, made themselves more profoundly felt. 'Plantation' agriculture lost all significance. The cost of labour, that had increased sharply under the influence of the wages paid at the refineries, gave the last blow to this always marginal industry. Gradually most of the plantation land came into the hands of the government or of Antillean and foreign investors. From these days onwards subsistence farming hardly rose above the level of allotment gardening. A completely new situation presented itself when at the end of the 1950's Bonaire's 'moneyorder' economy met troubles in its turn. As a result of an automatization program at the refineries numerous labourers were laid off (in 1952 21,101 people worked at the refineries, in 1972 only 4,828). ${ }^{4}$ Many Bonaireans returned to their native island and unemployment became a major problem in Bonaire, as well as on other islands of the Netherlands Antilles.

\section{Present-day resources}

What does Bonaire's economy look like now, how do people make a living now that agricultural activities practically ceased and the refineries offer jobs to only a few thousand Antilleans? Export statistics of the island are touchingly simple. In $1971^{\text {s }}$ Bonaire exported: 
106

ANK KLOMP

$745 \mathrm{~kg}$ aloë resin 58 sheep

49 goats 2721 crates of lemonade

$98933 \mathrm{~kg}$ charcoal $9116 \frac{10}{12}$ dozen products of small industry ${ }^{6}$

The 'products of small industry' mentioned, are the products of the ready made clothing industry, which is run by the government as a socio-economic development project. Self-evidently prime materials have to be imported. Often this factory, at which about 140 people find a job, has to be subsidized. The lemonade on the list comes from a factory at which about 10 labourers are employed. In 1972 a well-known Bonairean product of former days - salt could be added to the exports of the island; a North American company made a fresh start with the exploitation of the salt-pans in the south of Bonaire. Some 50 people have work at this company.

Herewith the enumeration of Bonairean products is completed. Other possible resources like, for instance, the tourist-industry are not very flourishing as yet. A few small hotels do pretty well, one of them being enlarged, but the only big hotel of an earlier date has to be kept going with government help. A recent development which is of significance for the island's economy is the establishment of an oil terminal (storage and transshipment): the first tankers moored in 1975. During the 8 years of tax-holiday which the AmericanDutch company enjoys, 125 people have to be kept at the payroll. The construction and enlargment of this terminal offered many more people an income, if only temporarily. More important is the favourable effect these activities seem to have on other sectors of the island's economy. ${ }^{7}$

This is all that Bonaire offers to its population as a means of subsistence; certainly not enough for its 9,000 inhabitants. Yet the Bonaireans do make a living and though the rate of unemployment normally amounts to about $20 \%$ of the working population, they do not live too badly either; so there have to be other sources of income. We have to look at the public finances to find these. On the budget of the island figures the so-called 'landsbijdrage', which is a contribution of the central government to the Bonairean treasury. This contribution is quite substantial. In 1971, the island budget showed a total amount of about 4 million NAfl. on the expenditure side, of which about 3,25 million were met by the central govern- 
Diagram of THE SYSTEM THROUGH WHICH THE MONEY FLOWS

Landsbijdrage

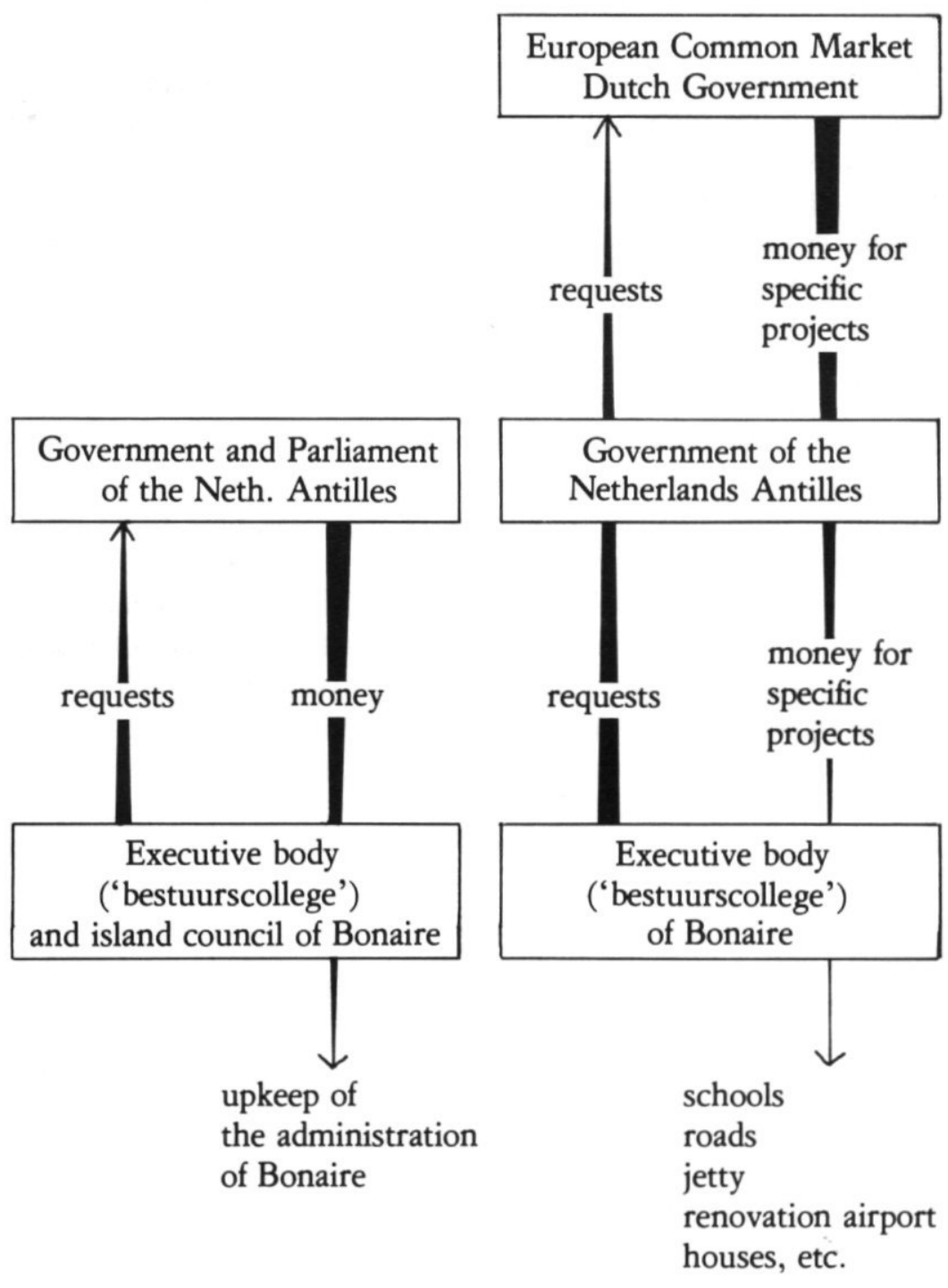


ment. ${ }^{8}$ Thus more than about $3 / 4$ of the island's regular finances comes from outside. But there are other resources too. These relate to the funds that are made available by the Dutch government and the European Common Market in the way of development aid. Under this heading Bonaire received about NAfl. 30,000,000 from 1959 up to and including 1971, which amounts to 2,3 million NAfl. a year. ${ }^{9}$ As to the destination of these contributions, the 'landsbijdrage' is used to keep up the administrative apparatus of Bonaire. In this respect it has to be kept in mind that the administration is the biggest employer ${ }^{10}$ and biggest customer on the island. The development aid money on the other hand, is given for specific projects, such as the building of a new jetty, enlarging and renovation of the airport, the building of schools etc.. These projects create jobs, if only temporarily, for a large number of construction workers and other labourers.

It may be clear from the diagram that the 'bestuurscollege' of Bonaire, together with its representative in the parliament, holds a pivotal position for the acquisition and allocation of the most important resources of the island, but at the same time these gatekeepers ${ }^{11}$ are in a position of dependency towards the Antilles central government. As will be explained, this situation implies that the Bonairean authorities act as (political) patrons to many Bonaireans on the one hand and are the (political) clients of the central government on the other hand.

\section{Politics}

The administration of the Netherlands Antilles is made up of a central government with a parliament located at Willemstad, Curaçao and of executive bodies and island councils for each of the island territories (the Bovenwinden: St. Maarten, St. Eustatius and Saba form administratively one 'island territory'). In the parliament, that counts 22 seats, Bonaire has 1 seat (Curaçao 12, Aruba 8 and the Bovenwinden together 1). The Bonairean executive ('bestuurscollege') consists of 3 members, the island council of 9 members. Of the executive body one member, the chairman, is the lieutenant-governor ('gezaghebber'), who is appointed by the crown on recommendation of the central government, the other two are the 
deputies, who are chosen by the members of the island council. Elections for the councils and the parliament, for which each island territory functions as a constituency, take place every four years. During the last ten years (1967-1977) this resulted in elections every other year, alternately for the island councils and for the parliament. The latter institution can be dissolved before its session time is over.

The relationship among the islands was laid down in the statutory regulations known as the 'Eilanden-regeling'. These enactments guaranteed each of the six island territories a great deal of autonomy, but there was one significant proviso: the budgets of those island territories which had a deficit at the time these regulations were enacted (1951), required the sanction of the central government. A second restriction to the autonomy of the island territories of this last category was that they were not allowed to contract loans. Bonaire and the Bovenwinden had a budgetary deficit; Aruba and Curaçao, homes of the oil refineries, in those days enjoyed a stronger financial position and were thus guaranteed a greater autonomy. Because of the restrictions mentioned, Bonaire is bound hand and foot to the central government, with the result that Bonaire's representative has to support every government because otherwise the island does not get enough funds. This may give rise to odd political alignments at Willemstad; the representative in question sometimes supports a party on the central level that is allied to his political opponent on the island's level. If, however, no party or coalition commands a majority in parliament, the one Bonairean vote may prove to have considerable value, possibly a decisive influence on the formation of a new government. In this case the Bonairean representative will try to rake in some profit: he may attempt to obtain a seat in the cabinet and of course he will ask for more money for Bonaire. The extent to which the island succeeds in attracting funds is not only important for the well-being of its citizens generally, but also determines whether the ruling politicians can come up to the expectations of individual Bonaireans towards them. To make that clear, the political scene on Bonaire itself has to be brought into the picture.

In 1971 four parties took part in the elections, the maximum number thus far. The body of adherents of a party shows the char- 
acteristics of a personal following. A party does not recruit its electorate on the basis of any particular ideology; it cannot be distinguished by regional criteria or by the somatic characteristics of its supporters, nor does it represent different classes in the community. Two factors give these parties their continuity over time: the personal attachment to a leader and a certain tradition in voting behavior.

Bonaire's politicians originate from all strata of society. In the beginning of the island's electoral history (the first elections on Bonaire for parliament were held in 1945; the first elections for the island council were in 1951), the shon were particularly active as politicians, but at about the middle of the 1950's politics became everybody's business.

As far as the internal organization is concerned, most parties are democratically organized, at least on paper. In practice, however, the leaders, sometimes with a few stalwarts, hold the reins of power. There are several explanations for this situation. In the first place, the leader of a party often is the party to a large degree; people vote for him personally. In the second place the members of a party do not form a well demarcated group, as there are hardly any 'objective' (i.e. non-personal) criteria for membership. For instance, if one would accept everybody who is willing to pay a membership fee, the danger that political opponents infiltrate, would be very real. On the other hand, it is impossible to expel people when they do not pay their subscription, because a person thus treated would immediately join the ranks of the opponents. The concentration of power in the party is faciliated by the docility of the followers. They are inclined to leave the management of the party to the leader and his assistents: 'the leader knows best'. The leader exploits this considerable leeway by inviting only the loyal and uncritical supporters to the meetings of the 'party council', the body that is supposed to take the most important decisions. The group of followers that is assembled in the party council consists for the greater part of so-called lider di bario, ward leaders. In every village (bario) a party has a few local representatives, who act as a sort of brokers ${ }^{12}$ between the partyleaders on the one side and the voters on the other side. They make propaganda for the party in their ward or village and check whether the adherents are still loyal ('who is seen 
with whom'). They also bring news (gossip) and general wishes and needs from the voters to the attention of the party-leaders. The lider di bario is a kind of broker for 'intelligence' 13 but his role is rather restricted. For personal requests the voter generally goes directly to the leader or one of the leaders of his party. In this respect it has to be kept in mind that everybody knows everybody on this island.

The party funds, especially the money needed for the elections, are drawn from various sources. Adherents may pay NAfl. 2.75 (1971) as a 'membership fee', while businessmen give money as well as material help. In addition, fund-raising parties are organised during the campaign and last but not least a party may get gifts from richer political allies on Curaçao or Aruba.

Given the fact that ideological differences do not exist between the parties on Bonaire and other criteria that could give them individual characteristics are also lacking, one might ask what determines voting behavior. This question is not so easy to answer. In this society, with its face to face relations, normally a number of motives are involved in the choice of a certain candidate or party and it is somewhat difficult to tell which role each of them plays. Analytically, however, we can discern the following considerations.

In the first place, what does a voter expect from the party or from the candidate he supports? The answer is: help. Of course a voter does expect the politicians to promote the interest of the island as a whole, but for the individual concerned, direct and concrete help is the crucial proof of a leader's worth. As to the kind of help wanted, there is an infinite range of possibilities, depending on the position and circumstances of the applicant. A. would like to have gravel on his yard, B. tries to have his run up waterbill remitted. In addition, one may look for: a job for oneself or one's child; a promotion, or tenure if one has already a job; a permit to start a business; business orders from the government; a set of teeth; a job in the rotation system for the unemployed; a grant; a loan etc..

It is clear that in most cases a politician can only deliver the goods, if he is 'in power', i.e. if his party constitutes the island's 'bestuurscollege' or has part in it. For that reason many vote for the party that is believed to have the best chance to win. But voting 
behavior is not only determined by pecuniary and other material motives. Loyalty is another important consideration. The party one first casts one's lot with, remains the party that has the strongest moral claim for further electoral support. A political party stands for a network of friends and acquaintances and therefore it is somewhat dishonourable to change sides: after all one should be true to one's friends. Of course the feelings of loyalty may have their origin in a favour that once has been bestowed. Other considerations that can be involved in choosing a certain party are family ties. In the first place in Bonaire it is hardly conceivable that a person votes for somebody else if a member of his own family is on a list; such behaviour would bring the good relations in a family under serious stress. In the second place there is a tendency for members of one family to vote for the same party. The kinship ties involved can also be a ritual kind, i.e. compadrazgo relations.

A last point to be touched upon is the personal like or dislike of a voter for a political leader. In a small island community such as Bonaire leaders are living in a 'glass house'; they are much more exposed to the observance of the people than the 'caudillo' in neighbouring Latin American countries. Many people feel strongly about he candidates on the basis of personal experience rather than hearsay. Thus feelings of personal attraction and dislike loom much larger than would be possible in a large scale society.

In résumé, the following of a political leader may be seen as consisting of clients; enemies of opponent; friends, acquaintances, sympathizers; relatives (of the leader, but also of the clients, enemies of the opponent, friends etc.).

The term following is used here for all the adherents of a leader whatever their kind of attachment. The relatives of the candidates, the friends, acquaintances, sympathizers and the enemies of the opponent form the core of the party; their attachment to the leader has moral, as well as transactional (i.e. materialistic) aspects. The attachment of the clients to the leader is primarily transactional. It will be clear that the meaning given to these terms here deviates from accepted anthropological usage. BAILEY (1969:45) for example sees the following as those adherents whose attachment to the leader is transactional; the core consists of retainers whose attachment is of a moral character. My main objection is to the definition 
of the core as having a purely moral character; after all, the relatives, friends etc. of a leader also expect and receive favours, their relationship to him also has pecuniary aspects. In Bonaire it is generally not so easy to tell transactional considerations from moral ones. Of course, there are people who vote primarily out of materialistic motives; however, the question is more complicated because a transactional tie implies a moral obligation and, conversely, a moral tie implies a transactional one. Thus if $\mathrm{A}$. is a politician who gave me a job. I am obliged to vote for him. Vice versa, if I voted for A. and he is in a position to help me, he cannot possibly refuse to do so. The fact that. 'help' in the materialistic sense creates the obligation to vote for a certain politician, gives Bonairean politics its transactional strain. To conclude from this, however, that every Bonairean votes primarily because of pecuniary motives, would be wide off the mark. That moral considerations play an important role in the behavior of the voters appears from the results of the elections: unsuccessful parties are able to retain their following to a considerable extent, in other words the core forms the majority of the following of a leader.

A few examples may illustrate actual voting behavior.

A. was a candidate of the X-party. An important government job was promised to him but he did not get it. A. felt cheated: he officially resigned his membership of the party and retired from active politics (he might have joined the opponent - there were only two parties at the time - but he considered that dishonourable). At the next elections he voted for the Y-party. His wife followed suit as did his sister-in-law and her husband, an aunt, the godmother of his wife and a blind old man, not related, whom he had often helped with small chores (the relatives mentioned were all A.'s close relatives present on the island).

B. was a loyal supporter of the X-party; in the past he had even been a candidate for that party. This relationship was cemented by family ties: B.'s daughter was married to the son of the founder of the X-party. Now this son divorced B.'s daughter in a rather unelegant way, reason for B. to join the ranks of the Y-party, the most outspoken political enemy of his former party. Several in-laws of B. were already adherents of the Y-party, also because of family-ties.

C., a single elderly lady, voted for the X-party because her father had told her that one of the founders of that party had always been good to the poor in the past. She only had a few relatives and all her friends belonged to the X-party. C. had never voted for another party even when it was far from succesful. The meetings were among the few outings she had.

D.'s relatives were well-known followers of the X-party. Her father had been a lider di bario and was often on the list of candidates. D. wanted a certain job for which she had the necessary diploma's. She went to see Harry R., leader of the Y-party. R. was Bonaire's representative in parliament and his party took part in the Bonaire's 'bestuurscollege'. Later at home, looking at the big portrait of the founder of the X-party, she commented to a friend: 'Now I have to vote for Harry, because he gave me the job'. 
Turning from the voters to the politicians, what can they do to collect votes? Feelings of sympathy can be influenced to a certain degree, reason why politicians pay many visits in election time, never miss a funeral, offer rides and smile a lot: personal attention is still highly appreciated on Bonaire. However, the main factor to be manipulated is the 'help' to voters. In this respect it makes of course a lot of difference whether a party dominates or takes part in the island's government or belongs to the opposition. It goes without saying that leaders of a government party enjoy a big advantage: they virtually have a monopoly of the commodities most in demand, such as jobs in the public service, either as employees or in the rotation system of the unemployed, of loans and permits. Moreover the government controls the distribution of water, decides about the location of new roads, the destination of certain pieces of land etc.

The politicians involved in the government use the possibilities connected with their position to the utmost. It is striking to notice how, prior to the elections the island rustles with activity; roads are being improved, new electrical connections made, constructions works that were at a standstill are brought to life again and so on. For these purposes numerous unemployed are put to work. These are activities observable for everyone, other rewards are less visible.

To try to ensure that votes, gathered in return for favours, go to the party that 'paid' for them, the possibilities to vote by proxy are used. In the Antilles one can vote by proxy if one cannot appear personally for some reason, such as illness or absence. The politicians have taken possession of this system so to speak; they have the forms of proxy in their pockets and try to get an authorization for a member of their party wherever possible. It has to be mentioned, however, that, in order to limit the abuse of the possibilities of voting by proxy, several restrictions have been inserted in the ballot act. This was the case in 1969 with regard to the elections for parliament and in 1973 for the elections of the island councils. Nevertheless, in 1969 still 424 requests to vote by proxy were granted, quite a lot on a total of 3564 valid votes. ${ }^{14}$

Another method to ensure that votes do not go 'the wrong way' is to make promises instead of rewards in advance. It will be clear that a promise will only be honoured and of course that is not even 
sure - when the party in question wins.

In view of the great advantage a government party has, the question arises whether a party that is in power can ever loose. History has proven that this is possible, but does not happen very often: since the first elections on Bonaire 1945, actually only two times.

The most important restriction on an undisturbed position of power of a certain party (or a coalition) is found in what might be called the 'finiteness of means', which can be translated in the 'finiteness of spoils'. There comes an end to the number of jobs to be fulfilled, to the number of places for the unemployed, to the goods to be ordered, to the loans, the permits etc.. This is especially true of Bonaire, an island with a permanent budgetary deficit. Because not all whishes can be complied with, not all favours granted and not all promises honoured, a group of dissatisfied people comes into being. These are the potential adherents of the opposition at future elections. But apparently dissatisfaction as such is too diffuse to have any striking capacity; it is a necessary condition for an assumption of power, but in itself not sufficient. In this respect it has to be realized that when a party or a coalition is in power for some time, the administration is infiltrated with its adherents. An opposition party therefore hardly means an attractive alternative to potential followers.

In 1955, when the first change of regime took place in Bonaire, it was a split in the ruling party that proved to be the sufficient condition for the overthrow. Here we come across a second major threat to the powerholders: trouble inside the party. A cleavage can be very dangerous as was shown in 1955; it offers the core the possibility to join another party and to be loyal at the same time. The second time government party on Bonaire suffered defeat was in 1969. The immediate cause was the May revolt on Curaçao. On the 30th of May 1969 shops and other buidings were burned down as part of a revolt which started with a march of workers and unemployed to Fort Amsterdam, the seat of the central government on Curaçao. In the days after the revolt union leaders forced the government to dissolve the parliament. Subsequent elections brought an end to the undivided sway of the D.P. (Democratic Party) in the central government. On Bonaire, in the wake of events on Curaçao, the 1969 elections brought about a landslide in 
favour of the opposition parties. The power of the Bonairean D.P. was further diminished by a split in its own ranks that took place shortly after these elections.

The May revolt thus proved to be the agens that converted the general dissatisfaction in an election success for the opposition.

However, when the well does not run dry, money and projects keep coming in and there is peace in the party, a government has a good chance to hold out for a long time. From the first elections in 1945 till 1955 the Bonairean United Party (after 1954, when another party joined, called the Bonairean Progressive United Party) was in power. After its overthrow in 1955, the Democratic Party ruled for almost 15 year (1955-1969). Since 1969, the year a fourth party was set up, the island is ruled by coalitions. However, one party is always represented and it is clear that its leader is the island's new 'big man'.

\section{Conclusion}

It will be clear from the foregoing that we have here a typical example of what is called political patronage. ${ }^{15}$ Of course it is not this political system as such that makes Bonaire an interesting case. On Aruba and Curaçao this system operates in virtually the same way ${ }^{16}$ and we have reports on this kind of politics for widely different countries. However, Bonaire stands out as a special case because of the extremely high percentage of government controlled resources. A comparison with Aruba and Curaçao may illustrate this point.

The table shows that on Bonaire approximately $50 \%$ of all earnings are derived from government resources or activities as to $\pm 33 \%$ on Aruba and $31 \%$ on Curaçao. (In reality the situation in all three islands is even more extreme because private business, such as the activities of contractors, depends to a large extent on funds that are made available as development aid by the Common Market and the Netherlands and these are also government controlled).

In view of the situation it is hardly surprising that on Bonaire politics are in the center of interest, as for many the weal and woe of 
WAGES, SALARIES AND SOCIAL CHARGES IN NAfl IN $1972^{17}$

\begin{tabular}{lccc}
\hline & Aruba & Curaçao & Bonaire \\
\hline $\begin{array}{l}\text { private enter- } \\
\text { prises }\end{array}$ & $88,423,000$ & $228,437,000$ & $5,476,000$ \\
$\begin{array}{l}\text { enterprises of } \\
\text { island govern- } \\
\text { ments }\end{array}$ & $5,952,000$ & $12,528,000$ & 518,000 \\
$\begin{array}{l}\text { island govern- } \\
\text { ment }\end{array}$ & $25,059,000$ & $49,830,000$ & $3,515,000$ \\
$\begin{array}{l}\text { enterprises of } \\
\text { the central govern- } \\
\text { ment plus central } \\
\text { government itself }\end{array}$ & $12,771,000$ & $41,905,000$ & $1,504,000$ \\
\hline
\end{tabular}

their party may affect their economic well-being: a $85 \%$ attendance or more at the elections is normal.

As to the 'gatekeepers' in the system, they are only effectively checked at election time. In this respect it has to be kept in mind - as may be clear from the diagram on p. 107 - that the choice of the projects to be paid by the Common Market or by the Netherlands is not subjected to the approval of the island's council. The latter, in fact, has only a say in the allocation of the 'landsbijdrage'. For the remainder it is the executive authority ('bestuurscollege') of the island, together with the representative of Bonaire in the parliament of the Antilles, that pull the strings. Besides, it has to be noted that the role of the island council in the process of decision-making on issues that are within its competence is generally also rather limited. The parties in the council usually vote as blocks; those supporting the B.C. will always vote in favour of the proposals of that body. When they stop doing so, it normally means that a political crisis is at hand. The 'bestuurscollege' in turn is at the mercy of the central government, at least when the vote of the Bonairean representative in parliament has no consequence for the position of the central government. 
1. I am indebted to H. HOETINK, A. DE RUIJTER, J.H. SCHERER and H.U.E. THODEN VAN VELZEN for valuable comments on an earlier draft.

2. For the socio-history of Curaçao the earlier work of HoETINK (1958) is the major source.

3. It has to be kept in mind that the Dutch terms 'Bovenwindse en Benedenwindse Eilanden' do not correspond with the English terms 'Windward and Leeward Islands.'

4. KoK, 1974, p. 24.

5. In this year the author lived on Bonaire, it serves as the etnographic present; the Netherlands Foundation for the Advancement of Tropical Research financed the research.

6. Verslag van de toestand van het eilandgebied Bonaire over bet jaar 1971

7. Verslag ... Bonaire over bet jaar 1977, p. 180.

8. In fact the situation in 1971 was even more unfavourable than appears from these figures. A report of the Audit Office shows an extra deficit of about 2 million NAfl... However, about 1976 the situation seems to have improved considerably, a.o. on account of the introduction of a system of wage-tax and probably of the effects of the activities of the oil terminal. Nevertheless the share of the contribution of the central government on the total expenditure of the island still amounts to nearly $50 \%$.

9. Amigoe di Curaçao 27.VII.1971.

10. Exact figures for 1971 are not available. In 1977, however, 555 people were employed by the island's government (Source: Begroting van het eilandgebied Bonaire voor het jaar 1977). People employed by services of the central government on Bonaire are not included in this number. See also table on p. 117.

11. 'Gatekeepers' as EASTON $(1965$, p. 86-96) calls them, are those persons who occupy strategic positions in a political system. The gatekeepers control the flow of demands, money, goods and services in the system; they may redirect the stream to favour certain groups or persons.

12. A (political) broker or middleman is a person who acts as in intermediate between people who control certain resources and people who want access to these resources. A patron controls certain resources himself, a broker only has contacts with people who do so (see BREMAN, 1971, p. 34; BoISSEVAIN, 1969, p. 380). As stated the lider di bario are only brokers in a very limited sense, as they are normally bypassed in case more important issues are at stake. 
13. Term used in this sense by van HekKen \& Thoden van Velzen, 1972, p. 38.

14. Partly the 'folklore' of voting by proxy belongs to the past; in 1977 the ballot act has been changed to the effect that voting by proxy for parliament is no longer possible; with regard to the election of the island council, however, nothing has been altered.

15. When political parties or functionaries give away jobs or hold out other rewards in exchange for electoral support, one speaks of political patronage. Other terms for this phenomenon are: 'machine politics', the 'spoil system' or 'bossism' (see for a comprehensive article BAX, 1975).

16. VERTON, 1977.

17. The figures for 1971 are not available. Source: Nationale Rekeningen 1972-1973 N.A., 1975 , I, p. 46.

18. The telephone service, the airport, the harbour, waterdistribution and public housing i.a. are counted under this heading.

19. Postal and Telegraph Services i.a. are counted under this heading.

\section{REFERENCES}

Abraham - van Der MARK, E.E.: Yu'i mama. Curaçao, 1969.

Amigoe di Curaçao, 27.I.1971 (daily paper).

BAILEY, F.G.: Strategems and Spoils. A Social anthropology of politics. Oxford, Blackwell, 1970.

BAx, M.: The political machine and its importance in the Irish Republic. In: Political Antbropology I, 1, 1975, pp. 6-21.

Begroting voor het eilandgebied Bonaire voor het jaar 1977.

EASTON, D.: A systems analysis of political life. New York, John Wiley \& Sons, Inc., 1965.

GreEN, D.: Migrants in Aruba. Assen, van Gorcum, 1974.

HekKen, P.M. van \& Thoden van Velzen, H.U.E.: Land scarcity and rural inequality in Tanzania. Den Haag, Mouton, 1972.

HottinK, H.: Het patroon van de oude Curaçaose samenleving. Assen, van Gorcum, 1958. 
KALM, F.: The dispersive and reintegrating nature of population segments of a third world society. Ann Arbor, Michigan, Univ. microfilms, 1975.

KOK, M.: De economische structuur van de Nederlandse Antillen. Curaçao, St. Augustinus Boekhandel, 1974.

Marks, A.F.: Male and female and the Afro-Curaçaoan bousebold. The Hague, Martinus Nijhoff, 1976.

Mintz, S.W.: The Caribbean as a sociocultural area. In : M.M. Horowitz ed, Peoples and cultures of the Caribbean. Garden City, New York, The Natural History Press, 1971, pp. 17-47.

Nationale Rekeningen, 1972-1973. Nederlandse Antillen. Nederlands Economisch Instituut, afd. Projecten, Curaçao, 1975.

RÖMER, R.A.: Un pueblo na kaminda. Curaçao, 1977. (Een volk op weg. Zutphen, Walburg Pers, 1978).

Verton, P.C.: Politieke dynamiek en dekolonisatie. Alphen aan de Rijn, Samsom, 1977.

Verslag van de toestand in bet eilandgebied Bonaire over bet jaar 1971. Bonaire, 1972.

Verslag ... Bonaire over bet jaar 1977. Bonaire, 1978.

Drs. ANK KLOMP

Dept. of Cultural Anthropology .

State University of Utrecht 